DIW BERLIN

Discussion

Papers

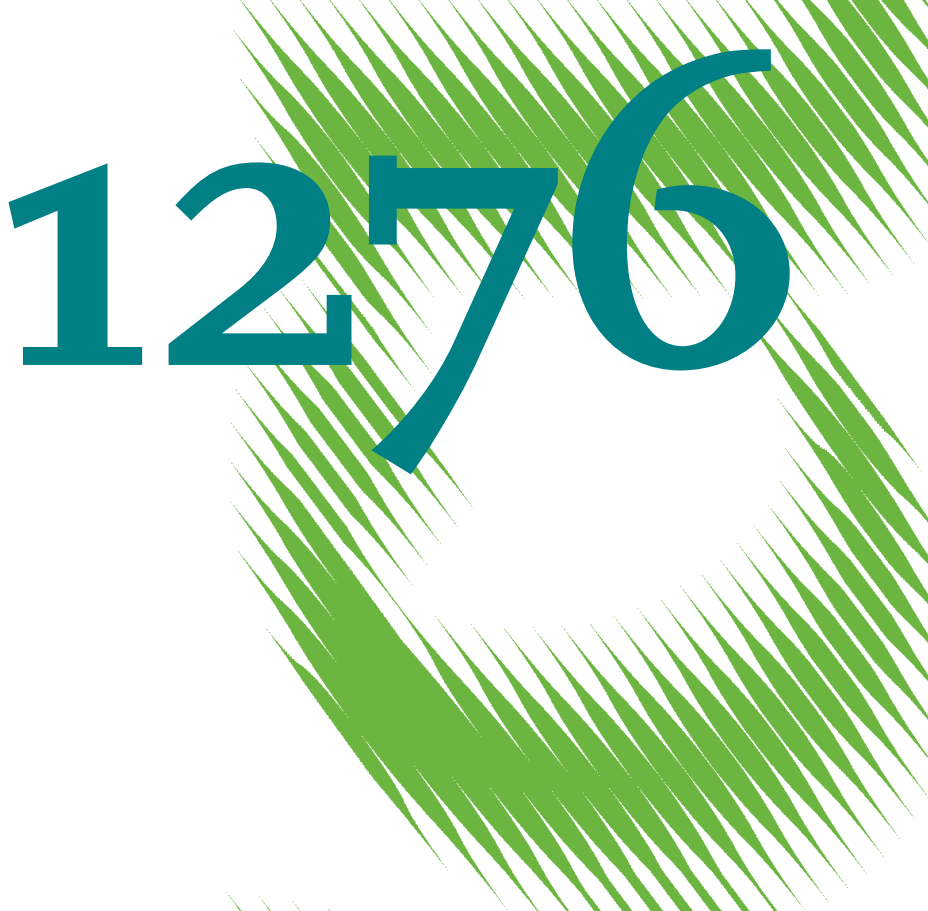

MMI

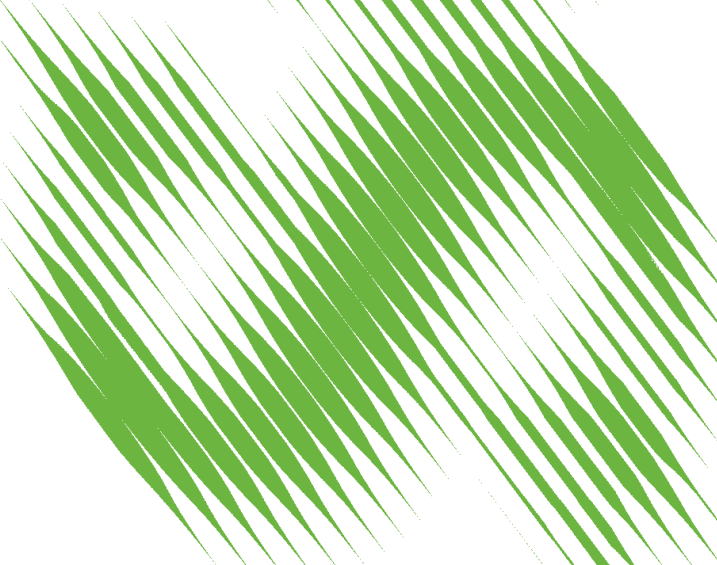

International Knowledge Spillovers through High-Tech Imports and R\&D of Foreign-Owned Firms 
Opinions expressed in this paper are those of the author(s) and do not necessarily reflect views of the institute.

IMPRESSUM

(C) DIW Berlin, 2013

DIW Berlin

German Institute for Economic Research

Mohrenstr. 58

10117 Berlin

Tel. $+49(30) 89789-0$

Fax +49 (30) $89789-200$

http://www.diw.de

ISSN print edition $1433-0210$

ISSN electronic edition 1619-4535

Papers can be downloaded free of charge from the DIW Berlin website:

http://www.diw.de/discussionpapers

Discussion Papers of DIW Berlin are indexed in RePEc and SSRN:

http://ideas.repec.org/s/diw/diwwpp.html

http://www.ssrn.com/link/DIW-Berlin-German-Inst-Econ-Res.html 


\title{
International Knowledge Spillovers through High-tech Imports and R\&D of Foreign-owned Firms
}

\author{
Heike Belitz \& Florian Mölders* \\ DIW Berlin
}

February 2013

\begin{abstract}
The international transmission of knowledge through import spillovers, as a source of TFP growth, has received much attention in the literature. We investigate two additional direct channels through which R\&D disseminates: the import of high-technology goods and the internationalization of business R\&D. Building on an extensive dataset, covering both developing and industrial countries, we add foreign owned patents as a proxy for R\&D activities of multinationals. While we confirm the significance of import spillovers for all countries included, we find additional spillovers for developing countries through the import of high-technology goods. Only developed economies seem to benefit from the diffusion of knowledge that originates through cross-border cooperation in R\&D by multinationals.
\end{abstract}

JEL-Classification: F14; F23; O47

Keywords: Productivity growth; Technology diffusion; Multinational enterprise

\section{Introduction}

Investments in R\&D are a significant driving force for a country's TFP growth (Bravo-Ortega and García Marín (2011)). These investments benefit not only countries that perform such activities but also foreign countries via cross-border knowledge flows. Trade and foreign direct investment (FDI) are examples of channels for knowledge spillovers. A more recent trend is the increasing internationalization of business R\&D, with cross-border flows of R\&D and significant shares of domestic R\&D performed by affiliates of foreign firms. Most R\&D investments abroad still go to OECD countries, but, starting in the 1990s, emerging economies increasingly became attractive locations for R\&D investments by multinationals from developed countries (OECD (2008)). In particular, cross-border R\&D cooperation within multinational companies is considered an ideal vehicle for the dissemination of knowledge.

Coe and Helpman (1995) first suggested a simple equation relating domestic TFP to domestic and foreign R\&D. Focusing on developed countries, they find a statistically significant relationship between the domestic and the foreign stock of R\&D capital. Their seminal study was followed by a fair number of research papers that focused on the increase of knowledge through international R\&D spillovers. They provide robust evidence that it is not only domestic but also foreign R\&D capital that are significant determinants of TFP growth for developed countries. For developing countries, though, the evidence on the nexus between TFP, domestic and foreign R\&D capital is much weaker. In the literature, imports and

*Corresponding author. Address: DIW Berlin, Mohrenstraße 58, 10117 Berlin, Germany. E-mail: fmoelders@diw.de. We thank Joscha Beckmann, Ansgar Belke, Jörg Breitung and Christian Dreger for helpful comments. 
FDI are considered to be the most important channel of international knowledge spillovers. In addition to this channel, there are various other means through which knowledge can flow between countries: human mobility (e.g. student flows), scientific publications or conferences, patenting and licensing. But there are great difficulties in putting together comparable data for these channels for both developed and developing countries.

Several empirical studies investigate knowledge spillovers through the channel of imports in industrialized countries (see e.g. Engelbrecht (1997), Keller (1998), Lichtenberg and Pottelsberghe de la Potterie (1998), Madsen (2008), Coe et al. (2009)). Most of these studies find that foreign knowledge spillovers through imports are significant determinants of the level of TFP. FDI is also considered a main channel to generate technological externalities and increase product market competition, both of which boost productivity and growth. However, studies for OECD countries provide mixed evidence on the influence of knowledge spillovers through FDI on TFP (van Pottelsberghe and Lichtenberg (2001), Lee (2006)). The results of van Pottelsberghe and Lichtenberg (2001) for a panel of 13 industrialized countries indicate that FDI transfers technology, but only in one direction: a country's productivity is increased if it invests in R\&Dintensive foreign countries but not if foreign $R \& D$-intensive countries invest in it. In contrast, Bitzer and Kerekes (2008) find that spillovers of knowledge through inward FDI are significant determinants of productivity, while they could not identify any effects from knowledge spillovers through outward FDI.

For developing countries, evidence on the nexus between TFP, domestic and foreign R\&D capital is less numerous. A study of 41 African countries between 1998 and 2006 finds that international trade remains an important conduit for technology transfer as characterized in the literature (Le (2012)). In addition, there is evidence that student flows effectively facilitate international technology diffusion from industrialized countries to less developed countries in Africa (Le (2010)). Further results indicate that the import channel is more conducive to knowledge spillovers than the FDI channel (Seck (2012)).

Our study focuses on spillovers through foreign knowledge transfer via trade, FDI and the internationalization of business R\&D using a panel of advanced and developing countries. Only few studies on international knowledge spillovers and productivity are based on such a mixed panel of countries (see e.g. Krammer (2010), Ang and Madsen (2012)). We extend the number of spillover measures for foreign R\&D capital stocks proposed by various papers using two new transfer channels: imports of high-tech goods and R\&D of foreign owned companies. Following Lichtenberg and Pottelsberghe de la Potterie (1998), the foreign knowledge stock is calculated using bilateral imports of high-tech goods weighted by the GDP of the partner country. Differences in the location of the patent owner and the respective inventor are used to measure cross-border knowledge flows via $R \& D$ of multinationals. These indicate R\&D activities of foreign companies and potential spillovers on domestic companies. From the perspective of the host country, international R\&D cooperation of multinational companies is an additional source of technological knowledge from abroad. Both transfer channels are new to the spillover literature. In contrast to the majority of studies, we measure R\&D stocks through the number of patent applications (at the priority date), which serves as a proxy of $\mathrm{R} \& \mathrm{D}$ expenditures. Using patent data also provides the opportunity to obtain data on the domestic R\&D stocks of developing countries.

We make use of patent data, provided by the OECD Patents Statistics, and follow Eberhardt et al. (2012) to estimate the panel cointegration relationship using common correlated effects estimators, as proposed by Pesaran (2006). Taking into account cross-sectional dependence allows us to control for various types of unobserved heterogeneous influences on the countries' TFP levels, such as their different absorptive capacities. The literature on productivity enhancing R\&D spillovers has, so far, missed out on this and mostly relied on traditional dynamic OLS (DOLS) or fully modified OLS (FMOLS) estimators, ignoring interdependencies among the explanatory variables.

Our estimates support the existence of spillovers through the import channel. In particular, the results 
suggest that imports of high-technology goods are beneficial for the productivity levels of developing countries. The internationalization of business $R \& D$ via respective activities of multinationals indicates a positive effect only for advanced economies, which suggests that this type of knowledge can only spillover above some development threshold level. FDI flows are only found to have a significant influence if crosssectional dependence is not taken into account. This result should, therefore, be treated with caution. Interestingly, the domestic knowledge stock as measured by the stock of patents on domestic inventions, does not suggest to have a significant influence on the TFP level across the majority of our regressions. This hints at the importance of foreign knowledge spillovers for the growth of a country's TFP, but, at the same time, also highlights the heterogeneous country coverage in our dataset. If the domestic knowledge stock is interacted with the dummy variable that labels developing countries, the coefficient for developed economies turns out significantly positive, whereas developing countries reflect no effect. The lack of influence of the domestic R\&D stock in our sample is, therefore, driven by the inclusion of low-income countries that largely source their productivity-increasing $R \& D$ through spillovers from high-technology imports.

The rest of our paper is structured as follows. Section 2 introduces the dataset and describes the variables of interest. Thereby, it also analyzes the time-series properties of the individual variables by testing for panel unit roots. In order to prepare for the econometric analysis in section 4 , we describe the respective methodology in section 3 . Section 5 concludes.

\section{Data}

We investigate the effect of international R\&D spillovers on TFP. In particular, we model this type of knowledge transmission with data on the internationalization of R\&D. The object of our investigation is the country and its level of TFP in particular. In the regression analysis we make use of data from 77 countries over a time-span of approximately 18 years between 1990 and 2008 The country coverage is highly heterogeneous in terms of per-capita incomes, as we consider low-income countries such as Zimbabwe and Mozambique, as well as OECD member countries, such as Australia, Germany and Luxembourg. The countries further reflect a high level of diversity in the sectoral specialization, as e.g. Kuwait and Qatar are included as representatives of high income resource rich economies. By increasing the heterogeneity of country characteristics in our data set, we aim to identify the R\&D spillover channels that influence TFP in a wide array of countries.

The knowledge transfer between countries is measured through spillover variables that are described in section 2.2. They are based on a transmission channel and the stock of knowledge in partner country $j$ at time $t$. This stock is calculated with the number of patent applications to the Patent Cooperation Treaty (PCT), at international phase, that designate the EPO (from 1978 onwards). According to the OECD (2009), the PCT is the most popular type of patent application for investors that target world markets 2 PCT applications can be seen as a form of worldwide application, even though it does not create a patent. Rather, it provides the inventor with the opportunity to acquire patent rights in the participant states of the PCT. In order to obtain a patent, national patent offices need to grant the application at a later stage. Until 2004, applicants had to designate which of the PCT signatory states in which he may wish to patent the invention 3 If the applicant designates countries covered by the EPO (European Patent Office), the application is known as a "Euro-PCT" application. It should be

$1 \quad$ Note that this number is subject to availability of the respective explanatory variables. For the majority of our regressions, we can report either 75 or 77 countries. Note also that Table 12 in the appendix lists 106 countries. This number is based on all countries for which data on TFP and knowledge stock, as well as any other data, is provided. However, for some countries there is insufficient information and are excluded from the regressions.

2 By the end of 2011 there were 144 signatory states to the PCT (WIPO $\sqrt{2012})$ ).

3 After 2004, all PCT contracting states are automatically included in the application. 
noted that several current PCT member states have become members in the 1990s and therefore data on PCT applications before 2000 should be treated with caution. The growth of patent counts may be overestimated due to multinationals in new member states that make increasingly use of this new form of applying for a patent. Nevertheless, our research question centers around the internationalization of business R\&D. We do not assume that the extension of the PCT system influences the application of patents from multinationals, as these international cooperation patents are most likely applied for by multinational enterprises whose host countries have long been members of the PCT (such as OECD member countries). However, in order to control for this potential bias, we check for robustness in section 4 using only EPO patent applications. Data on patent applications to the EPO have its disadvantages in the potential home bias which refers to the higher propensity for European companies to apply for a patent at the EPO, compared to non-European firms. European applicants, and their cooperation in $\mathrm{R} \& \mathrm{D}$ with foreign inventors, may therefore be overrepresented in this sample.

We make use of the priority date instead of the date when the patent was granted, as the latter may come with a considerable lag. Priority dates refer to the first filing worldwide and are therefore the closest indicator of inventive activity in any given year, $t$ (OECD (2009)). The OECD provides data for most countries (not only OECD member countries) on the number of applications in any year ${ }^{4}$ The database releases data on international cooperation in patenting such as the number of patents that are owned by foreigners but were invented by domestic residents. The respective indicator quantifies the extent to which foreign firms control domestic inventions and therefore reflects the role that foreign affiliates of multinational companies play in domestic R\&D activities. According to the OECD (OECD (2009)), the indicator measures the international collaboration by researchers within a multinational cooperation. Thus, the resulting figure mirrors the bilateral disembodied knowledge flows between home and host countries of a multinational firm.

\subsection{Data sources}

Our dependent variable describes the TFP for country $i$ in year $t$. We generate this variable as an index that has a value of 100 for every country in 2000. For the preceding and succeeding years, we make use of TFP growth rates from the Conference Board's Total Economy Database, which provides information on the growth of TFP for a wide range of countries over the period of observation starting in 1990 . The growth rate measures the change in GDP growth over the compensation-share weighted growth of combined factor inputs (labor and capital inputs, adjusted for change in their quality). To obtain TFP growth estimates, a standard growth accounting framework is used by the Conference Board to compute the contribution of these inputs to aggregate output (GDP) growth. In the production function, output is a function of labor and labor quality, capital (ICT and non-ICT), and TFP. Note that this is a narrower definition of TFP than is commonly used ${ }^{5}$

Data on bilateral trade flows is sourced from OECD's International Trade and Commodity Statistics database. We further discriminate between total and R\&D-intensive imports for the design of the knowledge spillovers ${ }^{6}$ R\&D-intensive goods are classified according to Hatzichronoglou (1997) and we sort medium-high and high technology industries into the R\&D-intensive group 7 For the transmission of foreign knowledge channeled through FDI, we make use of outward FDI from OECD member country $j$

4 See http://www.oecd.org/innovation/innovationinsciencetechnologyandindustry/oecdworkonpatentstatistics.htm.

5 See http://www.conference-board.org/retrievefile.cfm?filename=Methodological-Notes Jan2011.pdf\&type=subsite for methodological notes. TFP growth data can be accessed via http://www.conferenceboard.org/data/economydatabase/.

6 For the R\&D-intensive imports, we rely on data from UN Comtrade, accessed through World Bank's World Integrated Trade Solution.

7 Industries are classified according to the ISIC 2 classification. 
that is destined for any country $i \frac{8}{8}$ We thereby exclude any knowledge transfer from non-OECD member countries but we justify this procedure as we assume that the OECD countries are responsible for the vast majority of international knowledge transfer and the limited availability of FDI data for countries other than OECD ${ }^{9}$ Further, we cannot differentiate between different forms of FDI such as resource-seeking, export-oriented or efficiency-seeking FDI 10 Data on the countries' per-capita GDP and population levels are sourced from the Penn World Tables.

Figure 1 describes the development of four variables of interest for the empirical analysis. We aggregate countries according to their level of economic development and calculate the average value for any given year. From the upper left panel, we see that the growth of the average TFP level of developing countries surpasses the respective growth rate of the developed ("industrialized") countries since the beginning of the observation period. A similar development is depicted by the stock of domestic inventions, as measured by the cumulative number of domestic PCT patent applications (see lower left panel). The two remaining figures describe two spillover measures that are explained in greater detail in sub-section 2.2 . The average stock of foreign knowledge transmitted via the import of R\&D-intensive goods has been growing considerably faster in developing countries when compared to the group of developed economies since the beginning of our period of observation. The tendency of the development of the stock of foreign ownership of domestic inventions is more ambiguous, even though lower income economies are catching up from a significantly lower initial level.

\subsection{Spillover measures}

For the analysis of R\&D spillovers, we make use of four variables that describe potential spillovers from foreign $R \& D$. The first two measures (total as well as R\&D import spillovers) are referred to as spillovers from embodied R\&D. The transmission channel of the foreign knowledge stock are imports. We differentiate between total and R\&D-intensive imports in order to filter out imported goods that are supposed to include a great amount of embodied knowledge. In comparison to the spillover variable that is constructed from total imports as the transmission channel, R\&D imports may be expected to represent in greater detail the flow of knowledge between countries. The other two measures of foreign technology spillover refer to disembodied R\&D, as the transmission channels are (1) FDI flows or (2) active cooperations in business $\mathrm{R} \& \mathrm{D}$ activities, which we measure as the stock of foreign ownership of domestic inventions.

We follow Lichtenberg and Pottelsberghe de la Potterie (1998) in the weighting scheme of the spillover variables. The stock of import (as well as R\&D-import) spillovers therefore take the following form:

$$
\begin{aligned}
S_{i t}^{I m p} & =\sum_{j} \frac{M_{i j t}}{Y_{j t}} S_{j t}^{d}, \\
S_{i t}^{R \& D I m p} & =\sum_{j} \frac{R \& D M_{i j t}}{Y_{j t}} S_{j t}^{d},
\end{aligned}
$$

where $S_{i t}^{I m p}$ and $S_{i t}^{R \& D I m p}$ denote the stock of foreign patents that is transmitted by total $\left(M_{i j t}\right)$ and R\&D $\left(R \& D M_{i j t}\right)$ imports from country $j$ to country $i$ in period $t$. $Y_{j t}$ refers to the transmitting country's GDP and $S_{j t}^{d}$ to the domestic knowledge stocks of $j$. Hence, we weight the bilateral trade flow by the

8 See http://stats.oecd.org/Index.aspx?DatasetCode=FDI_FLOW_PARTNER\#-

9 In 2011, the group of developed countries were still responsible for around 82 percent of the world's outward FDI stocks (see UNCTAD FDI Statistics: http://unctadstat.unctad.org/TableViewer/tableView.aspx).

10 On the one hand, Javorcik and Spatareanu (2005) note that export-oriented affiliates are more likely to use high-quality inputs, hence leading to higher learning effects for suppliers. On the other hand, Javorcik (2004) finds some evidence for a positive spillover effect of domestic-market oriented FDI on the host country's productivity. 
GDP of the exporting country, instead of the total exports of country $j$. This approach replaces the share in total imports (between countries $i$ and $j$ ) with the share that the import value takes in the exporting countries' total produced output 11 With respect to the disembodied channel of FDI, we employ the same method and replace the import value with the FDI flow:

$$
S_{i t}^{F D I}=\sum_{j} \frac{F D I_{i j t}}{Y_{j t}} S_{j t}^{d}
$$

$F D I_{i j t}$ denotes the outflow of FDI from country $j$ that is designated for country $i$.

The spillover variable that is supposed to capture the cooperation between two countries in $R \& D$ is provided by the OECD's statistics on international cooperation in patents. The respective stock value is calculated as the cumulative number of patents invented by residents of country $i$, whose ownership rights belong to country $j$ :

$$
S_{i t}^{F O D I}=\sum_{j} S_{i j t}^{F O D I}
$$

Note that for each stock variable, we include a depreciation factor equal to 0.15 according to the perpetual inventory method (PIM). The respective values in the literature depend on the countries, years and sectors under observation $\sqrt{12}$ As mentioned in the previous sub-section, our period of observation starts in 1990. For most countries though, information on the number of patent applications goes back to 1978. The starting value for the stock of patents, $S^{d}$, therefore builds on the data until 1990.

\subsection{Unit root and cointegration tests}

Developments in the design of panel unit root (PURT) and cointegration tests provide the possibility to control for cross-sectional dependence in the data. Cross-sectional dependence can lead to biased estimation results if the unobserved common factor influences both the explanatory part of the equation as well as the dependent variable. If common factors are additionally non-stationary, they can lead to a rejection of a cointegration relationship even if the (observed) variables of interest are cointegrated.

In the following, we test all variables against the null hypothesis of having a unit root using first- as well as second-generation PURT. For the former, we employ the test proposed by $\operatorname{Im}$ et al. (2003) for heterogeneous panels ${ }^{13}$ For the latter generation, we plot the results of the Pesaran test (Pesaran (2007)). Panel A of Table (1) shows that most variables follow a unit root, based on the first generation PURT, with the exception of domestic patent applications $\left(S^{d}\right)$. In contrast to these findings, the second generation PURT delivers more ambiguous results. This test allows for the inclusion of cross-sectional averages of the respective variable on the right-hand side of the ADF test statistic and thereby partially controls for the unobservable common factor. This is also the main difference between these two unit root tests. Therefore, we present (Panel B of Table (1D) the test statistics of the Pesaran test on crosssectional dependence in the respective series (Pesaran (2004)). We find no indication of cross-sectional independence in the data. This result provides information on the differences between the PURT of the first and second generations. While all variables of interest exhibit some sort of cross-sectional dependence, only the Pesaran unit root test captures this characteristic. The ambiguous results are an

11 See Coe and Helpman (1995) for an application of the former approach.

12 See Bloom and Van Reenen $(2002)$ on the productivity of British firms, using a depreciation rate of 30 percent or Bottazzi and Peri (2007) who use a PIM factor of 0.1. We run robustness checks with a depreciation rate of 0.2 without significantly altering the results.

13 Heterogeneity is controlled for by averaging the individual unit root tests, hence the individual AR(1) coefficients of the augmented Dickey-Fuller (ADF) test. 
indication of a common factor, driving the unit root in some of the variables ${ }^{14}$ In conclusion, the test statistics call for the use of appropriate specifications to avoid spurious regressions. Therefore, in the empirical analysis, we employ residual diagnostics to check whether the residuals are stationary, which should be the case if the respective variables are cointegrated.

Following standard procedure in a panel analysis that deals with non-stationary variables, we also look at the results of traditional cointegration estimation techniques. If a set of variables is found to be cointegrated, the DOLS estimator proposed by Stock and Watson (1993) is expected to be superior (especially in small samples) over alternative methods such as OLS 15 Table 2 describes the panel cointegration test results for various model specifications, using two tests. The first, based on Pedroni (1999), tests for the null hypothesis of no cointegration in heterogeneous panels ${ }^{16}$ Note that, as reported by Örsal (2007), the respective panel $\rho$ and group $\rho$ statistics have low power in rejecting the null hypothesis if T is small. Furthermore, due to the heterogeneous set of countries included in our dataset, we feel more confident with using the results from the group statistics as an indicator of a cointegration relationship. This is due to the implied flexibility in comparison to the panel tests where the residuals are normalized before the test statistic is computed. As a second cointegration test, Table 2 presents the results from the Kao (1999) test. This alternative test is based on the assumption of homogeneity across panels. The results from the seven Pedroni tests are mixed: For the most part, the panel statistics do not reject the hypothesis of no cointegration, while the group statistics largely advise us to make use of cointegration estimation techniques. Similarly, the Kao test rejects the null hypothesis of no cointegration for all models. Based on these test statistics, we cannot ignore the possibility of a cointegration relationship unequivocally ${ }^{17}$

The following section describes our econometric approach in the presence of cross-sectional dependent and non-stationary variables. We rely on post-estimation residual diagnostic tests in order to check for stationarity and cross-sectional dependence in the residual 18 These tests then provide information on the quality of the underlying specification.

\section{Specification}

Based on the time-series and cross-sectional structure of our data, we have to choose from among the available econometric methods. System GMM (as proposed by Blundell and Bond (1998)) relies on stationary variables, large cross-sections, and on the homogeneity of the slope parameters of the estimated equation. In the presence of a cointegration relationship among the dependent and independent variables, panel cointegration methods are suitable for the analysis of non-stationary data that include a substantial amount of time-series information. Representatives of the panel cointegration approach, which are similar to the research question of the present paper, are Coe and Helpman (1995), Coe et al. (2009) and Madsen (2008).

The literature increasingly focuses on the regression misspecification that arises if common unobserved factors are not controlled for in the regression analysis of panel cointegration. We implement an estimation

14 We have also tested all variables of interest for a unit root in first-differences, in order to test for integration of the second order. The IPS test unanimously rejects the hypotesis of a unit root in first differences whereas the Pesaran test gives out more ambigious results regarding the two import and the FDI spillover variables.

15 If, in the presence of cross-sectional dependent variables, we find the residual to be non-stationary, the estimators proposed by Pesaran (2006) can account for the unobserved common factors and thereby correct for a missing cointegration relationship between the variables of interest. See section 3 for further discussion on the specifications.

16 Pedroni (1999) reports seven test statistics that can be split into Panel and Group statistics. The within tests assume that the AR(1) term in the cointegration regression is the same across cross-sections and the test statistics are computed by pooling along the time-series dimension. The group statistics pool accordingly along the cross-sectional dimension (group-mean). Rejection of the null hypothesis for the group statistics implies that there exists at least one cointegration relationship among the cross-sections.

17 Gutierrez 2003) states that, after testing both the Pedroni and Kao tests in a Monte Carlo simulation, the Kao test performs much better than Pedroni's test if the time-dimension is small, as it is the case for our study.

18 See Banerjee et al. (2010) for a study on testing residual properties in a panel data context. 
strategy that sequentially controls for the effect of unobserved common factors on TFP and that is, thereby, robust against cross-sectional dependence. This method is proven to be robust against nonstationary regressors, even in the case of no cointegration relationship between the included variables (see Kapetanios et al. (2011)).

In a two-way fixed effects regression, we only control for unobservables that are specific to each group, but constant across time (country fixed effects), or for unobservables that are common between groups but homogeneous in their effect on the dependent variable (year fixed effects). Additionally, there may be factors that are common to the cross-sections, but unobservable in their nature and heterogeneous in their effect on the dependent variable. If these factors are correlated with one of the covariates, this induces an endogeneity problem, as both the TFP level and the potential spillover effects are simultaneously affected. Thus, cross-sectional dependence introduces a source of bias and, increasingly so, with a higher correlation between the unobservable common factors and the covariates, which translates into the degree of unobserved cross-sectional dependence in the data. Furthermore, if the unobservable common factors are non-stationary, this may result in spurious regression 19

Exemplarily, we consider the following equation:

$$
y_{i t}=\underbrace{\alpha_{i} d_{t}+\theta_{i} h_{i t}}_{\beta_{i} x_{i t}}+\underbrace{\gamma_{i} f_{t}+\varepsilon_{i t}}_{u_{i t}}
$$

where the dependent variable $y_{i t}$ is determined by common observable factors, such as $d_{t}$ as well as common unobservable factors, denoted by $f_{t}$ (with country specific factor loadings $\alpha_{i}$ and $\gamma_{i}$ ). If $d_{t}$ and $f_{t}$ are correlated, an endogeneity problem arises and we end up with inconsistent estimates as the coefficient $\beta_{i}$ is not properly identified. Pesaran (2006) introduces a pooled common correlated effects (CCEP) estimator that controls for cross-sectional dependence via the inclusion of cross-sectional averages that are interacted with country dummies in order to allow for country-specific parameters of the crosssectional dependence. Nevertheless, this estimator does not control for heterogeneous slope parameters of the explanatory variables. In our context, heterogeneity in the slope coefficients may arise due to differences in absorptive capacity between countries ${ }^{20}$ Griffith et al. (2003) e.g. argue that the level of a country's TFP is also determined by its potential to absorb technology or to internalize the knowledge that was not created by the country itself. Some economies are better able to adapt to the knowledge gained from spillovers from multinationals. These activities by multinationals include exports and FDI, as well as the direct cooperation with a foreign affiliate in R\&D. As our dataset includes both developed and developing economies, and hence a supposedly high level of heterogeneity in the absorptive capacity, we cannot claim that our available control variables fully capture all country characteristics. Pesaran (2006) additionally proposes a mean-group CCE estimator (CCEMG) that mixes the common factor approach of the CCE estimator with the mean-group estimator, proposed by Pesaran and Smith (1995). This mean-group estimator allows for heterogeneous slope parameters while it additionally controls for cross-sectional averages of the dependent and independent variables in the regression. It thereby accounts for the type of endogeneity that was addressed before, namely the correlation between the regressors and the error term, which is based on the common unobservable factors (Eberhardt and Bond (2009)).

In equation 6, we state the basic econometric model (in the case presented here, e.g. the two-way fixedeffects model) that will be adjusted in the empirical analysis to fit the R\&D spillover variables previously discussed. The equation relates the TFP of country $i$ in year $t$ to its level of stocks of domestic patent

19 Kapetanios et al. (2011) explicitly allow the unobservable common factors to follow a unit root process. The authors "observe that again the results accord with the conclusions reached in the stationary case, lending further support to the use of the CCE [common correlated effects] estimators irrespective of the order of integration of the data observed." (p. 338).

20 The notion of absorptive capacity is described by Cohen and Levinthal (1989) at the firm level. Abramovitz (1986) links the capability of a country to adapt technological changes to the country's level of education. 
inventions $\left(S_{i t}^{d}\right)$ and a spillover effect $S_{i t}^{X}$, which may refer to any of the spillover measures $S_{i t}^{\operatorname{Im} p}, S_{i t}^{R \& D I m p}$, $S_{i t}^{F D I}$ or $S_{i t}^{F O D I}$ :

$$
\log \left(T F P_{i t}\right)=\alpha_{i}+\delta_{t}+\beta_{1} \log \left(S_{i t}^{d}\right)+\beta_{2} \log \left(S_{i t}^{X}\right)+\varepsilon_{i t}
$$

where $\alpha_{i}$ denotes a country-specific and $\delta_{t}$ a year fixed-effect.

In the empirical part of this paper, we proceed as follows in order to sequently control for idiosyncratic and common unobservables: In the first step, a two-way fixed effects model serves as the baseline specification and panel unit root and cross-sectional dependence residual tests are performed to test the accuracy of the model. In order to take the cointegration relationship into account, we estimate a DOLS regression. This method (see Stock and Watson (1993), Saikkonen (1991)), is considered to be superior in small samples, as opposed to other specifications such as OLS (Kao and Chiang (2001)), even though it is based on the assumption of cross-sectional independence ${ }^{21}$ We then allow for pooled common correlated effects as well as the mean-group equivalent, as proposed by Pesaran $(2006){ }^{22}$

\section{Results}

In the following, we present the results from the two-way fixed effects, DOLS, CCEP and CCEMG estimators ${ }^{23}$ For each specification, the results for knowledge spillovers on TFP through imports, R\&Dimports, FDI, as well as foreign ownership of domestic inventions, are described. The residuals are then tested for non-stationarity and cross-sectional dependence in order to evaluate the quality of the respective results. Note that each of the aforementioned estimators differs in terms of their assumptions with respect to the handling of common correlated factors as well as dynamics. The unit root tests performed in section 2 support the assumption that our variables of interest exhibit non-stationarity and the respective cointegration tests cannot reject a cointegration relationship unanimously.

We begin with the fixed-effects model that accounts for unobserved time-invariant individual factors and common year effects. Table 3 shows quite clearly that our variables of interest, which describe the spillover effects, suggest a positive influence on the countries' TFP level. In contrast to this finding, we find ambiguous results with respect to the domestic knowledge stock. For some regressions, the respective coefficient even suggests a negative influence. The strongest spillover effects, in magnitude of the coefficient, can be found in the variables that include imports (in total, as well as R\&D). As a measure of accuracy, the root mean squared error (rmse) indicates a good fit of the respective models. Interestingly, the residual test on cross-sectional dependence does not reject the null hypothesis of crosssectional independence. The post-estimation test statistics reveal non-stationarity in the residual of all the regressions performed in Table 3 . The two-way fixed effects specification is not expected to deliver unbiased results due to the asymptotic bias if the regressors are not strictly exogenous (Pedroni (2001)). Therefore, in Table 4, we show the results of the DOLS regressions, using two lags and leads for the variables in first-differences. Note that we were unable to capture post-estimation diagnostics for the PURT as well as for the test on cross-sectional dependence, as the time-series dimension of our dataset is too small (after the computing the leads and lags in the DOLS regressions) to properly compute the respective test statistics. The results, which have therefore to be considered with hindsight, confirm

21 The DOLS estimator consists of an OLS regression that additionally includes lags and leads of the first-differenced covariates.

22 The regressions in the following section are computed using STATA 12 and user-written commands for the CCEP and CCEMG regressions (xtmg by Markus Eberhardt), as well as for the Pesaran PURT and test on cross-sectional independence (pescadf by Piotr Lewandowski and xtcd by Markus Eberhardt).

23 DOLS: dynamic ordinary least squares, CCEP: pooled common correlated effects, CCEMG: mean group common correlated effects. All specifications in Tables 3.8 were estimated without a time trend. 
the first impression from the two-way fixed effects model: the spillover variables are (highly) significant and point toward a TFP enhancing effect. Even if the effect of the spillovers is estimated jointly, their significance levels remain. Similar to Table 3 , an effect of the domestic patent stock cannot be confirmed. This suggests that TFP growth is primarily affected by knowledge spillovers from abroad, rather than from the domestic R\&D stock. The conclusion from these first two model specifications in Tables 3 and 4 would be to support the assertion that import spillovers matter the most for TFP growth, whereas we also find evidence for positive spillover effects from FDI and R\&D-cooperation spillovers. The latter leads to an increase in the TFP level of 4.5 percent if the stock of foreign owned patents doubles. The respective increase is almost two percentage points larger for spillovers that are transmitted through FDI flows.

The approach proposed by Pesaran (2006) takes into account unobserved common factors and potential stationarity and non-stationarity of the included variables. In the following step, we apply the pooled CCE and its respective mean-group equivalent to our data. Table 5 describes the estimates, which are based on the CCEP estimator. The results differ from the previous specifications, as only the import spillover channel is identified as a determinant of a country's TFP level. The residual tests are in favor of the pooled CCE specification as both PURT and cross-sectional dependence tests indicate stationarity and cross-sectional independence. Domestic knowledge, measured through the stock of domestic inventions, again fails to indicate a positive relationship with the TFP level.

In order to allow for even greater flexibility, we advance from the pooled CCE estimator to its mean-group equivalent ${ }^{24}$ The CCEMG implies OLS estimation for each cross-section and averages the resulting coefficients for the mean-group estimator, while it also includes the cross-sectional averages that were introduced in the pooled CCE. This allows for heterogeneity in the individual countries' parameters. The mean-group CCE regressions in Table 6 provide us with new findings: while the results again suggest a positive influence of overall import spillovers on TFP, R\&D-intensive imports (as a sub-group of total imports) also indicate a TFP enhancing effect. The domestic patent stock again does seem to have any influence on the TFP ${ }^{25}$ The PURT and cross-sectional independence test-statistics for the residual reject the hypothesis of cross-section independence for the regressions of total as well as R\&D imports, while also rejecting the hypothesis of a unit root for all models in Table 6

The results so far indicate that spillovers to TFP exist. They are most prominent for imports, hence through the embodied knowledge in the imported goods. However, the findings further suggest that R\&D imports, as a subcategory of total imports, also have a significantly positive influence, just like spillovers weighted by FDI flows (for some of the regressions). Foreign ownership of domestic inventions partially reveals significant coefficients. In the following, we further want to exploit the heterogeneity in the country-coverage of our dataset. Therefore, we include a dummy variable that indicates whether country $i$ was considered a developing country in period $t \sqrt{26}$ We then interact this dummy with the respective spillover variables to check whether there exist different effects for these two groups. We use the pooled CCE specification for this purpose as it is shown to be robust in the presence of cross-sectional dependent as well as non-stationary variables 27 The alternative mean-group estimator relies on the group specific

$24 \quad$ Due to its problem with spurious regressions, we refrain from describing the results from the standard mean-group estimator, as proposed by Pesaran and Smith (1995), but we refer the reader to the appendix (Table 9 for the respective results. In the appendix, you can also find Table 11 which includes the regression results for the System GMM estimates. We do not describe the respective results in detail as this specification is highly sensitive with respect to the number of lags and instruments.

25 The equivalent to the specification in Table 6 including a time trend, can be found in Table 10 The coefficients and significance levels all point towards the same direction.

26 The status of a country as being developed/developing is determined by the respective per-capita income level and the threshold values provided by the World Bank (http://siteresources.worldbank.org/DATASTATISTICS/Resources/OGHIST.xls). Accordingly, countries that were considered low-income and lower-middle income by the World Bank in period $t$ are labeled developing whereas the upper-middle and high income countries are considered to be developed.

27 Compared to the mean-group CCE estimator, the pooled version has the additional advantage that it is expected to 
results and, hence, on the within variation of the regressors. The pooled equivalent of the cross-sectional dependence consistent estimator (CCEP) pools the data for estimation and therefore additionally includes the cross-sectional variation in the data.

The results in Table 7 clearly indicate a heterogeneous effect of $R \& D$ import spillovers. The marginal effect of a 100 percent increase in knowledge spillovers transmitted via R\&D-intensive imports on the TFP level amounts to 5 percent for developing countries and only 1.7 percent for developed economies. Conversely, foreign ownership of domestic inventions suggests to have a converse effect on the two country groups: whereas we observe a significantly positive coefficient for developed economies, there is no indication of a benefit for developing countries from this sort of cooperation in $\mathrm{R} \& \mathrm{D}{ }^{28}$ The post-estimation diagnostic tests suggest that we do not have to deal with non-stationary or cross-sectional dependent residuals, similar to the CCEP estimates without interaction terms in Table 5 .

To evaluate the validity of our results, we rely on the residual diagnostic tests on stationarity and cross-sectional dependence. Even though the two-way fixed effects model exposes interesting correlations (highly significant coefficients throughout all of our spillover variables), we are forced to reject this specification due to non-stationary residuals. Similar findings, regarding the coefficients, are delivered using dynamic OLS, which is expected to be unbiased if a cointegration relationship exists among the included variables. Due to the presence of cross-sectionally dependent variables (see Table 1) and the partially ambiguous cointegration test statistics in Table 2, we proceed to pooled CCE, which is expected to be robust even if the included variables are not cointegrated. The statistically significant regressors are then reduced to the import spillover variables. CCEMG regressions underline this finding but additionally suggest positive spillovers via R\&D-intensive imports and foreign ownership of domestic inventions. Interaction effects that discriminate between developed and developing countries further signal stronger spillovers though imports of R\&D-intensive goods for the latter group of countries, whereas the former group benefits more through the internationalization of $\mathrm{R} \& \mathrm{D}$ via foreign ownership of the domestic inventions. According to our estimations, the domestic R\&D stock does not indicate any positive influence on a country's TFP. Yet, we have estimated a regression in which we interact the domestic knowledge stock with the dummy variable that labels countries as developed/industrialized ${ }^{29}$ We find that, as soon as we discriminate between these two groups of countries, the coefficient for the domestic patent stock of developed countries becomes significantly positive, whereas we cannot identify any effect for the developing countries.

The regression results so far are based on domestic and foreign knowledge stocks, measured through the application of PCT patents. As a robustness check, we provide results based on the knowledge stock, as measured through patent applications to the $\mathrm{EPO}{ }^{30}$ The data coverage is comparable to the PCT case. We replicate the estimates for the Tables discussed, for patents applied to the PCT for the EPO patent data. Overall, the results do not differ in terms of coefficient signs, significance levels and residual diagnostic tests. We refrain from a full description of the respective Tables but rather focus on a single specification that we think nicely sums up the main results. The previous Table (Table 7) indicates a difference in the effect of R\&D import spillovers and foreign ownership of domestic inventions for higher and lower per-capita income countries. A replication of this specification, using EPO patent data, is presented in Table 8 . The similarity of the results in evident from the signs and significance levels. There is some evidence that $R \& D$ imports have a stronger effect on the TFP in developing countries. In contrast to the findings based on PCT data, we do not find any significant positive influence of perform better in small samples (Pesaran $(2006))$.

28 The respective interaction term is not significant. The resulting marginal effect does have a positive sign but without any statistical significance.

29 The respective regression results are available upon request.

30 Note that EPO patents suffer from a home bias, as European applicants have a higher propensity to apply for a patent at the EPO that non-European applicants. 
the variables denoting foreign ownership of domestic inventions, neither for developing nor developed economies.

\section{Conclusion}

This paper analyzes the effect of spillovers through the import of $R \& D$-intensive goods and $R \& D$ of foreign-owned firms. In order to take the R\&D activity into account, we make use of data on patent applications filed under the PCT. Data from the EPO is used for as a robustness check. In our empirical analysis, we employ various specifications that take into account the non-stationarity of our data. Given that we cannot exclude cross-sectional dependence, common correlated effects estimators, as proposed by Pesaran (2006), are employed due to robustness against unobservable interdependencies in the crosssections.

According to the different specifications, we can assert that spillovers through the import channel seem to matter for TFP growth. We thereby confirm previous findings in the literature (e.g. Madsen (2008), Coe et al. (2009)). Depending on the applied specification, R\&D-intensive imports are conducive for increasing TFP, especially for developing countries. This is consistent with findings that stress the relevance of R\&Dintensive capital goods imports for developing countries (Hoekman et al. (2005)). The internationalization of business $R \& D$ via respective activities of multinationals only indicates a positive effect for advanced economies, which suggests that this type of knowledge spills over above some development threshold level. FDI flows are only found to have a significant influence if cross-sectional dependence is not taken into account. This result should therefore be treated with caution. Interestingly, the domestic knowledge stock, as measured by the stock of patents on domestic inventions, does not suggest a significant influence on the TFP level across the majority of our regressions. This hints at the importance of foreign knowledge spillovers for the growth of a country's TFP 31 but also brings back in mind the heterogeneous country coverage in our dataset. The interaction of the domestic knowledge stock with the dummy variable that labels developing countries results in a significantly positive coefficient for developed economies, while we find no effect for developing countries.

Our results add to the empirical literature on R\&D spillover effects by including a highly heterogeneous set of countries. Furthermore, we approximate the respective countries' R\&D stocks with the number of patent applications. This abstracts from the conventional approach of using R\&D expenditures but largely confirms the existing results on import spillover effects. The result that R\&D-intensive imports are relevant for the dissemination of knowledge towards developing countries is novel, as well as the indication that R\&D of foreign owned firms is beneficial to the TFP growth of developed countries. Our results imply that liberalization of trade should be promoted in developing countries to enhance their TFP. Especially trade barriers on imports of R\&D intensive goods should be removed. The internationalization of $R \& D$ in multinational companies is a relatively new channel through which knowledge spreads across industrialized countries. In these countries, a research policy that aims at attracting and better embedding foreign-controlled $R \& D$ into the national innovation system would support international R\&D spillovers. Nevertheless, we should note that our measure of the knowledge stock based on European PCT applications is far from perfect. Simple patent counts are only a weak proxy for the input of R\&D because they reflect not only variations in innovative performance but also in the propensity to patent (de Rassenfosse and van Pottelsberghe (2009)). Future research could benefit from better data on patent values. A further source of knowledge dissemination, neglected in this paper, is licensing trade. This type of services

31 See also Hall et al. (2009) on the relative importance of foreign R\&D for countries that have either small or large domestic R\&D expenditures. The authors state that countries that spend less on R\&D are more likely to gain from foreign inflows of knowledge. 
trade should be taken into account, given that appropriate data is available, as its weight in international commerce has increased substantially.

\section{References}

Abramovitz, M. (1986). Catching up, forging ahead, and falling behind. Journal of Economic History $46(2), 385-406$.

Ang, J. B. and J. B. Madsen (2012, March). International R\&D spillovers and productivity trends in the asian miracle economies. Monash Economics Working Papers 03-12, Monash University, Department of Economics.

Banerjee, A., M. Eberhardt, and J. J. Reade (2010). Panel estimation for worriers. Discussion Paper 10-33, University of Birmingham.

Bitzer, J. and M. Kerekes (2008). Does foreign direct investment transfer technology across borders? New evidence. Economics Letters $100(3), 355$ - 358.

Bloom, N. and J. Van Reenen (2002). Patents, real options and firm performance. Economic Journal 112(478), 97-116.

Blundell, R. and S. Bond (1998). Initial conditions and moment restrictions in dynamic panel data models. Journal of econometrics 87(1), 115-143.

Bottazzi, L. and G. Peri (2007). The international dynamics of R\&D and innovation in the long run and in the short run. Economic Journal 117(518), 486-511.

Bravo-Ortega, C. and A. García Marín (2011). R\&D and productivity: A two way avenue? World Development 39(7), 1090-1107.

Coe, D. T. and E. Helpman (1995). International R\&D spillovers. European Economic Review 39(5), 859-887.

Coe, D. T., E. Helpman, and A. W. Hoffmaister (2009). International R\&D spillovers and institutions. European Economic Review 53(7), 723-741.

Cohen, W. M. and D. A. Levinthal (1989). Innovation and learning: The two faces of R\&D. Economic Journal 99(397), 569-596.

de Rassenfosse, G. and B. van Pottelsberghe (2009). A policy insight into the R\&D-patent relationship. Research Policy 38(5), 779-792.

Eberhardt, M. and S. Bond (2009). Cross-section dependence in nonstationary panel models: a novel estimator. Working Paper 17692, MPRA.

Eberhardt, M., C. Helmers, and H. Strauss (2012). Do spillovers matter when estimating private returns to R\&D? forthcoming Review of Economics and Statistics.

Engelbrecht, H.-J. (1997). International R\&D spillovers, human capital and productivity in OECD economies: An empirical investigation. European Economic Review 41(8), 1479 - 1488.

Griffith, R., S. Redding, and J. V. van Reenen (2003). R\&D and absorptive capacity: Theory and empirical evidence. Scandinavian Journal of Economics 105(1), 99-118. 
Gutierrez, L. (2003). On the power of panel cointegration tests: a monte carlo comparison. Economics Letters $80(1), 105-111$.

Hall, B. H., J. Mairess, and P. Mohnen (2009). Measuring the returns to R\&D. NBER Working Paper 15622, National Bureau of Economic Research.

Hatzichronoglou, T. (1997). Revision of the high-technology sector and product classification. OECD Science, Technology and Industry Working Papers 1997/02, OECD.

Hoekman, B. M., K. E. Maskus, and K. Saggi (2005). Transfer of technology to developing countries: Unilateral and multilateral policy options. World Development 33(10), 1587-1602.

Im, K. S., M. H. Pesaran, and Y. Shin (2003). Testing for unit roots in heterogeneous panels. Journal of Econometrics 115(1), 53-74.

Javorcik, B. S. (2004). Does foreign direct investment increase the productivity of domestic firms? In search of spillovers through backward linkages. American Economic Review 94(3), 605-627.

Javorcik, B. S. and M. Spatareanu (2005). Disentangling fdi spillover effects: What do firm perceptions tell us? In T. H. Moran, E. M. Graham, and M. Blomström (Eds.), Does FDI Promote Development? New Methods, Outcomes and Policy Approaches. Institute for International Economics.

Kao, C. (1999). Spurious regression and residual-based tests for cointegration in panel data. Journal of Econometrics 90(1), 1-44.

Kao, C. and M.-H. Chiang (2001). On the estimation and inference of a cointegrated regression in panel data. In B. H. Baltagi, T. B. Fomby, and R. C. Hill (Eds.), Nonstationary Panels, Panel Cointegration, and Dynamic Panels (Advances in Econometrics, Volume 15). Emerald Group Publishing.

Kapetanios, G., M. H. Pesaran, and T. Yamagata (2011). Panels with non-stationary multifactor error structures. Journal of Econometrics 160(2), 326-348.

Keller, W. (1998). Are international R\&D spillovers trade-related? analyzing spillovers among randomly matched trade partners. European Economic Review 42(8), 1469-1481.

Krammer, S. M. (2010). International R\&D spillovers in emerging markets: The impact of trade and foreign direct investment. Journal of International Trade ES Economic Development 19(4), 591-623.

Le, T. (2010). Are student flows a significant channel of R\&D spillovers from the north to the south? Economics Letters 107(3), 315-317.

Le, T. (2012). R\&D spillovers through student flows, institutions, and economic growth: What can we learn from african countries? Scottish Journal of Political Economy 59(1), 115-130.

Lee, G. (2006). The effectiveness of international knowledge spillover channels. European Economic Review 50(8), 2075-2088.

Lichtenberg, F. R. and B. v. Pottelsberghe de la Potterie (1998). International R\&D spillovers: A comment. European Economic Review 42(8), 1483-1491.

Madsen, J. B. (2008). Economic growth, TFP convergence and the world export of ideas: A century of evidence. Scandinavian Journal of Economics 110(1), 145-167.

OECD (2008). The internationalisation of business R\&D: Evidence, impacts and implications. Report, Organisation for Economic Co-operation and Development. 
OECD (2009). OECD patent statistics manual. Report, Organisation for Economic Co-operation and Development.

Örsal, D. D. K. (2007). Comparison of panel cointegration tests. SFB 649 Discussion Paper 2007-029, Humboldt University, Berlin.

Pedroni, P. (1999). Critical values for cointegration tests in heterogeneous panels with multiple regressors. Oxford Bulletin of Economics and Statistics 61 (S1), 653-670.

Pedroni, P. (2001). Fully modified OLS for heterogenous cointegrated panels. In B. H. Baltagi, T. B. Fomby, and R. C. Hill (Eds.), Nonstationary Panels, Panel Cointegration, and Dynamic Panels, Volume 15, pp. 93-130. Emerald Group.

Pesaran, M. H. (2004). General diagnostic tests for cross section dependence in panels. IZA Discussion Paper 1240, Institute for the Study of Labor, Bonn.

Pesaran, M. H. (2006). Estimation and inference in large heterogeneous panels with a multifactor error structure. Econometrica 74(4), 967-1012.

Pesaran, M. H. (2007). A simple panel unit root test in the presence of cross-section dependence. Journal of Applied Econometrics 22(2), 265-312.

Pesaran, M. H. and R. Smith (1995). Estimating long-run relationships from dynamic heterogeneous panels. Journal of Econometrics 68(1), 79-113.

Saikkonen, P. (1991). Asymptotically efficient estimation of cointegration regressions. Econometric Theory 7(1), 1-21.

Seck, A. (2012). International technology diffusion and economic growth: Explaining the spillover benefits to developing countries. Structural Change and Economic Dynamics 23(4), 437-451.

Stock, J. H. and M. W. Watson (1993). A simple estimator of cointegrating vectors in higher order integrated systems. Econometrica 61(4), 783-820.

van Pottelsberghe, B. and F. R. Lichtenberg (2001). Does foreign direct investment transfer technology across borders? Review of Economics and Statistics 83(3), 490-497.

WIPO (2012). PCT yearly review - the international patent system. WIPO economics \& statistics series, World Intellectual Property Organization. 


\section{$6 \quad$ Figures and Tables}

Figure 1: Plots of variables, Index $(2000=100)$
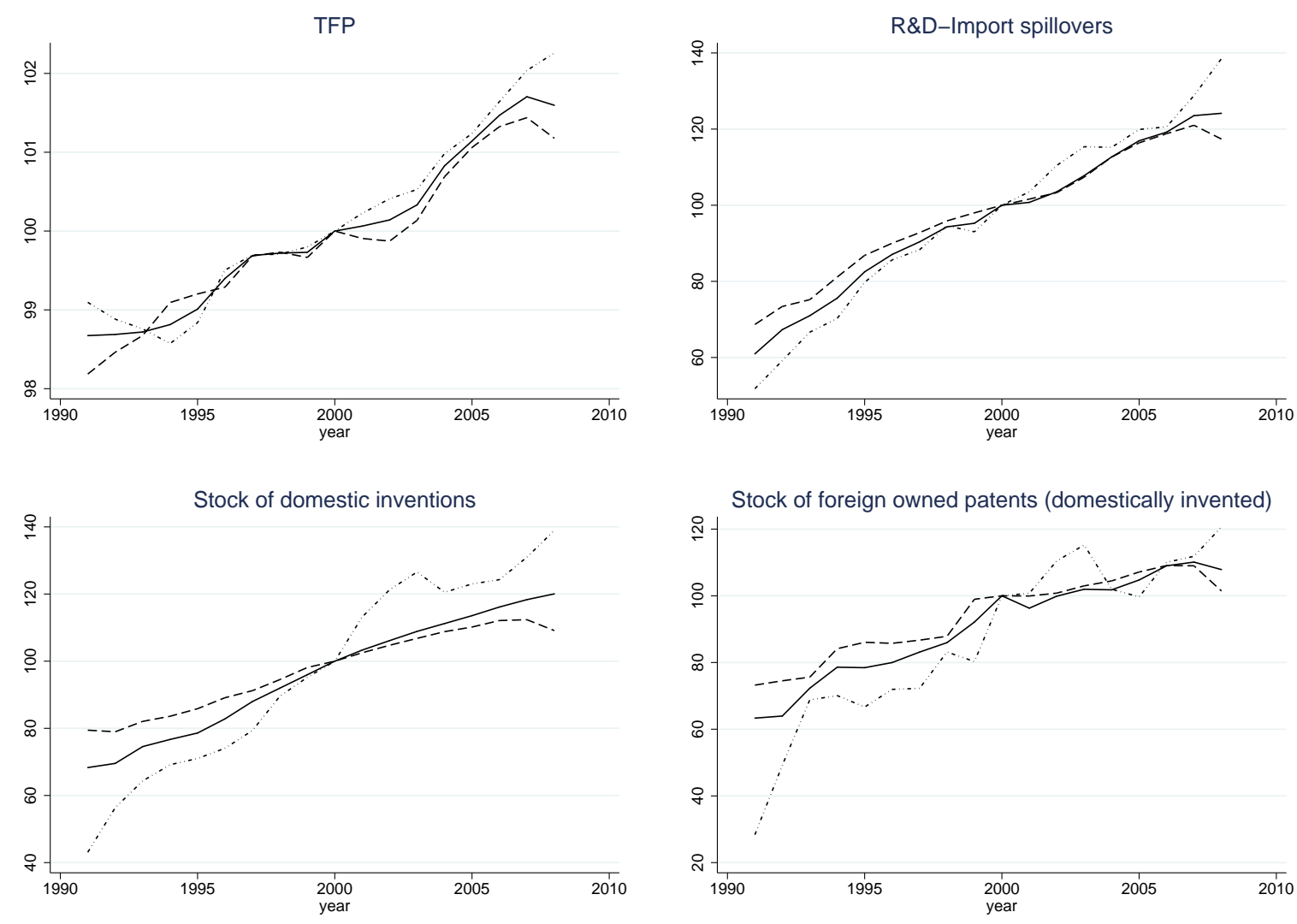

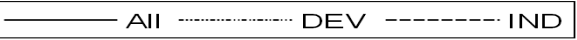

Notes: "All" refers to the full sample average, "DEV": developing countries,

"IND": industrialized/developed countries. Y-axis scaled in logs.

Table 1: PURT and CD-test

\begin{tabular}{l|cc|c}
\hline \multirow{2}{*}{ Variable } & \multicolumn{2}{|c|}{ Panel A: PURT } & Panel B: CD-test \\
\cline { 2 - 4 } TFP & $\mathrm{IPS}$ & $\mathrm{Pesaran}$ & Pesaran \\
$S^{d}$ & $\mathrm{I}(1)$ & $\mathrm{I}(0) / \mathrm{I}(1)$ & $62.54^{* * *}$ \\
$S^{I m p}$ & $\mathrm{I}(0)$ & $\mathrm{I}(0)$ & $218.87^{* * *}$ \\
$S^{R \& D I m p}$ & $\mathrm{I}(1)$ & $\mathrm{I}(0) / \mathrm{I}(1)$ & $207.46^{* * *}$ \\
$S^{F O D I}$ & $\mathrm{I}(1)$ & $\mathrm{I}(0) / \mathrm{I}(1)$ & $201.58^{* * *}$ \\
$S^{F D I}$ & $\mathrm{I}(1)$ & $\mathrm{I}(1)$ & $211.46^{* * *}$ \\
\multicolumn{2}{l}{ Notes: PURT refers to panel unit root test by $/ 7^{* * *}$} \\
\hline
\end{tabular}

Notes: PURT refers to panel unit root test by Im et al. (2003) and Pesaran (2007). Lag length for IPS and Pesaran tests based Akaike selection applied to the underlying time-series specification; CD-test refers to Pesaran (2004) test statistic for cross-sectional dependence. H0 in CD test: cross-sectional independence. $\mathrm{I}(0)$ : no unit root, $\mathrm{I}(1)$ : unit root. 


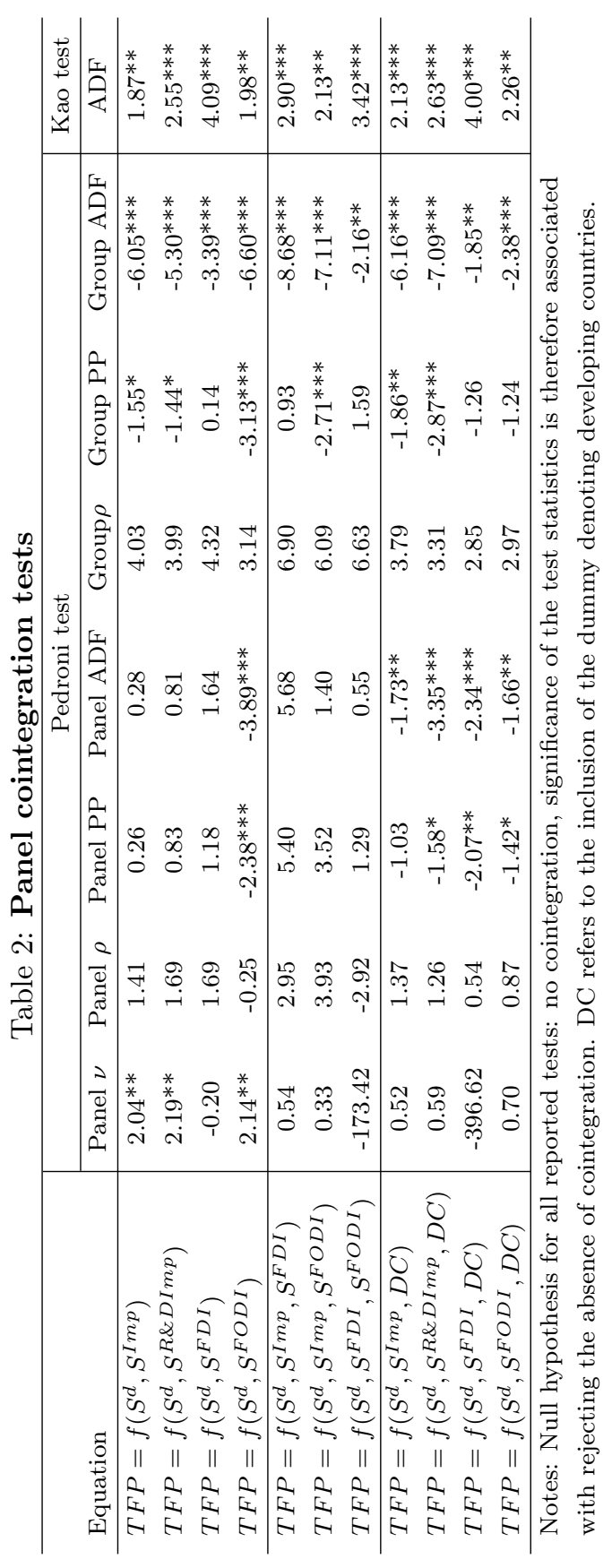


Table 3: 2 fixed-effects (id, year)

\begin{tabular}{lccccccc}
\hline \hline & $(1)$ & $(2)$ & $(3)$ & $(4)$ & $(5)$ & $(6)$ & $(7)$ \\
& TFP & TFP & TFP & TFP & TFP & TFP & TFP \\
\hline Dom Patents & 0.006 & $0.012^{* *}$ & $0.015^{* *}$ & $-0.014^{* *}$ & 0.004 & $-0.021^{* * *}$ & $-0.015^{* *}$ \\
& $(0.005)$ & $(0.006)$ & $(0.006)$ & $(0.006)$ & $(0.006)$ & $(0.006)$ & $(0.006)$ \\
Imports & $0.108^{* * *}$ & & & & $0.101^{* * *}$ & $0.109^{* * *}$ & \\
& $(0.014)$ & & & & $(0.014)$ & $(0.014)$ & \\
R\&D Imports & & $0.058^{* *}$ & & & & & \\
& & $(0.024)$ & & & & & \\
FDI & & & $0.011^{* * *}$ & & $0.006^{* * *}$ & & $0.011^{* * *}$ \\
& & & $(0.002)$ & & $(0.002)$ & & $(0.002)$ \\
FODI & & & & $0.054^{* * *}$ & & $0.045^{* * *}$ & $0.054^{* * *}$ \\
& & & & $(0.009)$ & & $(0.008)$ & $(0.010)$ \\
\hline Observations & 1350 & 1365 & 1324 & 1461 & 1216 & 1334 & 1309 \\
rmse & 0.071 & 0.073 & 0.077 & 0.079 & 0.069 & 0.069 & 0.076 \\
\hline \hline
\end{tabular}

Standard errors in parentheses

* $p<0.10, * * p<0.05, * * * p<0.01$

Notes: Country and year fixed-effects included. "Dom. Patents" denotes the number of domestic patents, "Imports", "R\&D Imports" and "FDI" denote spillover effects from foreign knowledge transmitted via total, R\&D-intensive imports and FDI respectively. "FODI" refers to "Foreign ownership of domestic inventions" and the associated spillover effect. "rmse" denotes the root-mean-square error.

Table 4: Dynamic OLS

\begin{tabular}{lccccccc}
\hline \hline & $(1)$ & $(2)$ & $(3)$ & $(4)$ & $(5)$ & $(6)$ & $(7)$ \\
& TFP & TFP & TFP & TFP & TFP & TFP & TFP \\
\hline Dom Patents & 0.006 & 0.010 & -0.000 & $-0.017^{*}$ & -0.001 & $-0.018^{* *}$ & $-0.026^{* * *}$ \\
& $(0.007)$ & $(0.007)$ & $(0.008)$ & $(0.009)$ & $(0.007)$ & $(0.009)$ & $(0.010)$ \\
Imports & $0.112^{* * *}$ & & & & $0.086^{* * *}$ & $0.097^{* * *}$ & \\
& $(0.016)$ & & & & $(0.015)$ & $(0.014)$ & \\
R\&D Imports & & $0.119^{* * *}$ & & & & & \\
& & $(0.011)$ & & & & & \\
FDI & & & $0.064^{* * *}$ & & $0.049^{* * *}$ & & $0.067^{* * *}$ \\
& & & $(0.006)$ & & $(0.006)$ & & $(0.006)$ \\
FODI & & & & $0.045^{* * *}$ & & $0.048^{* * *}$ & $0.054^{* * *}$ \\
& & & & $(0.014)$ & & $0.012)$ & $0.018)$ \\
\hline Observations & 938 & 954 & 663 & 1076 & 584 & 922 & 657 \\
rmse & 0.049 & 0.049 & 0.048 & 0.065 & 0.040 & 0.047 & 0.047 \\
\hline \hline
\end{tabular}

Standard errors in parentheses

* $p<0.10, * * p<0.05, * * * p<0.01$

Notes: Year fixed-effects included. "Dom. Patents" denotes the number of domestic patents, "Imports", "R\&D Imports" and "FDI" denote spillover effects from foreign knowledge transmitted via total, R\&D-intensive imports and FDI respectively. "FODI" refers to "Foreign ownership of domestic inventions" and the associated spillover effect. "rmse" denotes the root-mean-square error. 
Table 5: Pooled CCE

\begin{tabular}{lccccccc}
\hline \hline & $(1)$ & $(2)$ & $(3)$ & $(4)$ & $(5)$ & $(6)$ & $(7)$ \\
& TFP & TFP & TFP & TFP & TFP & TFP & TFP \\
\hline Dom Patents & 0.008 & $0.009^{*}$ & $0.011^{*}$ & 0.009 & 0.010 & 0.007 & 0.011 \\
& $(0.006)$ & $(0.006)$ & $(0.006)$ & $(0.008)$ & $(0.006)$ & $(0.008)$ & $(0.009)$ \\
Imports & & & & & & & \\
& $0.084^{* * *}$ & & & & $0.069^{* * *}$ & $0.098^{* * *}$ & \\
& $(0.009)$ & & & & $(0.011)$ & $(0.009)$ & \\
R\&D Imports & & 0.016 & & & & & \\
& & $(0.012)$ & & & & & \\
FDI & & & 0.001 & & -0.001 & & 0.001 \\
& & & $(0.001)$ & & $(0.001)$ & & $(0.001)$ \\
FODI & & & & $0.016^{*}$ & & 0.004 & 0.006 \\
& & & & $(0.009)$ & & $(0.008)$ & $(0.011)$ \\
\hline Observations & 1350 & 1365 & 1324 & 1461 & 1216 & 1334 & 1309 \\
rmse & 0.029 & 0.029 & 0.039 & 0.033 & 0.030 & 0.027 & 0.035 \\
\hline \hline Standard & & & & & & & \\
\hline
\end{tabular}

Standard errors in parentheses

${ }^{*} p<0.10,{ }^{* *} p<0.05,{ }^{* * *} p<0.01$

Notes: Country and year fixed-effects included. CCE: common correlated effects (estimator). "Dom. Patents" denotes the number of domestic patents, "Imports", "R\&D Imports" and "FDI" denote spillover effects from foreign knowledge transmitted via total, R\&D-intensive imports and FDI respectively. "FODI" refers to "Foreign ownership of domestic inventions" and the associated spillover effect. "rmse" denotes the root-mean-square error.

Table 6: Mean-group CCE

\begin{tabular}{lccccccc}
\hline \hline & $(1)$ & $(2)$ & $(3)$ & $(4)$ & $(5)$ & $(6)$ & $(7)$ \\
& TFP & TFP & TFP & TFP & TFP & TFP & TFP \\
\hline Dom Patents & 0.006 & -0.001 & 0.005 & 0.003 & 0.005 & -0.023 & -0.025 \\
& $(0.007)$ & $(0.007)$ & $(0.006)$ & $(0.016)$ & $(0.008)$ & $(0.019)$ & $(0.016)$ \\
Imports & $0.059^{* * *}$ & & & & $0.046^{* * *}$ & $0.053^{* * *}$ & \\
& $(0.013)$ & & & & $(0.013)$ & $(0.010)$ & \\
R\&D Imports & & $0.047^{* * *}$ & & & & & \\
& & $(0.009)$ & & & & & \\
FDI & & $0.003^{*}$ & & 0.001 & & $0.004^{* *}$ \\
& & & $(0.002)$ & & $(0.001)$ & & $0.001)$ \\
FODI & & & & $0.025^{*}$ & & 0.026 & $0.039^{* *}$ \\
& & & & $(0.015)$ & & $(0.019)$ & $(0.017)$ \\
\hline Observations & 1350 & 1365 & 1324 & 1461 & 1216 & 1334 & 1309 \\
\hline \hline
\end{tabular}

Standard errors in parentheses

$* p<0.10,{ }^{* *} p<0.05,{ }^{* * *} p<0.01$

Notes: Trend included. CCE: common correlated effects (estimator). "Dom. Patents" denotes the number of domestic patents, "Imports", "R\&D Imports" and "FDI" denote spillover effects from foreign knowledge transmitted via total, R\&D-intensive imports and FDI respectively. "FODI" refers to "Foreign ownership of domestic inventions" and the associated spillover effect. 
Table 7: Pooled CCE, with Interaction terms

\begin{tabular}{|c|c|c|c|c|}
\hline & $\begin{array}{c}(1) \\
\text { TFP }\end{array}$ & $\begin{array}{c}(2) \\
\text { TFP }\end{array}$ & $\begin{array}{c}(3) \\
\text { TFP }\end{array}$ & $\begin{array}{c}(4) \\
\text { TFP }\end{array}$ \\
\hline Dom Patents & $\begin{array}{c}0.008 \\
(0.005)\end{array}$ & $\begin{array}{c}0.009 \\
(0.005)\end{array}$ & $\begin{array}{c}0.016^{* * *} \\
(0.006)\end{array}$ & $\begin{array}{r}0.006 \\
(0.009)\end{array}$ \\
\hline Dev. Country Dummy & $\begin{array}{c}-0.112 \\
(0.084)\end{array}$ & $\begin{array}{c}-0.176^{* *} \\
(0.054)\end{array}$ & $\begin{array}{c}0.031 \\
(0.036)\end{array}$ & $\begin{array}{c}0.131^{*} \\
(0.072)\end{array}$ \\
\hline Imports & $\begin{array}{c}0.079^{* * *} \\
(0.011)\end{array}$ & & & \\
\hline Dev Country*Imports & $\begin{array}{c}0.021 \\
(0.015)\end{array}$ & & & \\
\hline R\&D Imports & & $\begin{array}{c}0.017^{* *} \\
(0.007)\end{array}$ & & \\
\hline Dev Country*R\&DImports & & $\begin{array}{c}0.033^{* * *} \\
(0.010)\end{array}$ & & \\
\hline FDI & & & $\begin{array}{c}0.002 \\
(0.002)\end{array}$ & \\
\hline Dev Country*FDI & & & $\begin{array}{l}-0.004 \\
(0.003)\end{array}$ & \\
\hline FODI & & & & $\begin{array}{c}0.036^{* * *} \\
(0.013)\end{array}$ \\
\hline Dev Country*FODI & & & & $\begin{array}{c}-0.023^{*} \\
(0.013) \\
\end{array}$ \\
\hline $\begin{array}{l}\text { Observations } \\
\text { rmse }\end{array}$ & $\begin{array}{l}1350 \\
0.027\end{array}$ & $\begin{array}{l}1365 \\
0.027\end{array}$ & $\begin{array}{l}1324 \\
0.036\end{array}$ & $\begin{array}{l}1461 \\
0.030\end{array}$ \\
\hline
\end{tabular}

Standard errors in parentheses

Country and year fixed-effects included

${ }^{*} p<0.05,{ }^{* *} p<0.05,{ }^{* * *} p<0.01$

Notes: Country and year fixed-effects included. CCE: common correlated effects (estimator). "Dom. Patents" denotes the number of domestic patents, "Imports", "R\&D Imports" and "FDI" denote spillover effects from foreign knowledge transmitted via total, R\&D-intensive imports and FDI respectively. "FODI" refers to "Foreign ownership of domestic inventions" and the associated spillover effect. "rmse" denotes the root-mean-square error. 
Table 8: Pooled CCE, with Interaction terms (EPO)

\begin{tabular}{|c|c|c|c|c|}
\hline & $\begin{array}{c}(1) \\
\text { TFP }\end{array}$ & $\begin{array}{c}(2) \\
\text { TFP }\end{array}$ & $\begin{array}{c}(3) \\
\text { TFP }\end{array}$ & $\begin{array}{c}(4) \\
\text { TFP }\end{array}$ \\
\hline Dom Patents & $\begin{array}{c}0.014 \\
(0.009)\end{array}$ & $\begin{array}{l}0.020^{* *} \\
(0.009)\end{array}$ & $\begin{array}{c}0.024^{* * *} \\
(0.008)\end{array}$ & $\begin{array}{c}0.002 \\
(0.018)\end{array}$ \\
\hline Dev. Country Dummy & $\begin{array}{c}-0.168^{*} \\
(0.094)\end{array}$ & $\begin{array}{c}-0.221^{* * *} \\
(0.061)\end{array}$ & $\begin{array}{l}-0.034 \\
(0.027)\end{array}$ & $\begin{array}{l}0.316^{* *} \\
(0.141)\end{array}$ \\
\hline Imports & $\begin{array}{c}0.069^{* * *} \\
(0.015)\end{array}$ & & & \\
\hline Dev Country*Imports & $\begin{array}{c}0.028^{*} \\
(0.016)\end{array}$ & & & \\
\hline R\&D Imports & & $\begin{array}{l}0.016^{* *} \\
(0.007)\end{array}$ & & \\
\hline Dev Country*R\&DImports & & $\begin{array}{c}0.037^{* * *} \\
(0.011)\end{array}$ & & \\
\hline FDI & & & $\begin{array}{c}0.001 \\
(0.002)\end{array}$ & \\
\hline Dev Country*FDI & & & $\begin{array}{c}-0.003 \\
(0.003)\end{array}$ & \\
\hline FODI & & & & $\begin{array}{c}0.054 \\
(0.033)\end{array}$ \\
\hline Dev Country*FODI & & & & $\begin{array}{c}-0.051^{* *} \\
(0.025)\end{array}$ \\
\hline $\begin{array}{l}\text { Observations } \\
\text { rmse }\end{array}$ & $\begin{array}{l}1373 \\
0.034\end{array}$ & $\begin{array}{l}1388 \\
0.035\end{array}$ & $\begin{array}{l}1353 \\
0.039\end{array}$ & $\begin{array}{l}1482 \\
0.037\end{array}$ \\
\hline
\end{tabular}

Standard errors in parentheses

Country and year fixed-effects included

${ }^{*} p<0.1,{ }^{* *} p<0.05,{ }^{* * *} p<0.01$

Notes: Country and year fixed-effects included. CCE: common correlated effects (estimator). "Dom. Patents" denotes the number of domestic patents, "Imports", "R\&D Imports" and "FDI" denote spillover effects from foreign knowledge transmitted via total, R\&D-intensive imports and FDI respectively. "FODI" refers to "Foreign ownership of domestic inventions" and the associated spillover effect. "rmse" denotes the root-mean-square error. 


\section{A Appendix}

Table 9: Mean group estimator

\begin{tabular}{|c|c|c|c|c|c|c|c|}
\hline & $\begin{array}{c}(1) \\
\text { TFP }\end{array}$ & $\begin{array}{c}(2) \\
\text { TFP }\end{array}$ & $\begin{array}{c}(3) \\
\text { TFP }\end{array}$ & $\begin{array}{c}(4) \\
\text { TFP }\end{array}$ & $\begin{array}{c}(5) \\
\text { TFP }\end{array}$ & $\begin{array}{c}(6) \\
\text { TFP }\end{array}$ & $\begin{array}{c}(7) \\
\text { TFP }\end{array}$ \\
\hline Dom Patents & $\begin{array}{c}0.001 \\
(0.008)\end{array}$ & $\begin{array}{l}-0.006 \\
(0.007)\end{array}$ & $\begin{array}{c}0.001 \\
(0.008)\end{array}$ & $\begin{array}{l}-0.017 \\
(0.015)\end{array}$ & $\begin{array}{c}0.004 \\
(0.007)\end{array}$ & $\begin{array}{c}-0.014 \\
(0.019)\end{array}$ & $\begin{array}{r}-0.015 \\
(0.018)\end{array}$ \\
\hline Imports & $\begin{array}{c}0.053^{* * *} \\
(0.011)\end{array}$ & & & & $\begin{array}{c}0.057^{* * *} \\
(0.012)\end{array}$ & $\begin{array}{c}0.061^{* * *} \\
(0.011)\end{array}$ & \\
\hline R\&D Imports & & $\begin{array}{c}0.060^{* * *} \\
(0.010)\end{array}$ & & & & & \\
\hline FDI & & & $\begin{array}{c}0.005^{* *} \\
(0.002)\end{array}$ & & $\begin{array}{c}0.003^{*} \\
(0.002)\end{array}$ & & $\begin{array}{c}0.005^{* * *} \\
(0.002)\end{array}$ \\
\hline FODI & & & & $\begin{array}{c}0.012 \\
(0.016)\end{array}$ & & $\begin{array}{c}0.011 \\
(0.017)\end{array}$ & $\begin{array}{c}0.013 \\
(0.018)\end{array}$ \\
\hline Observations & 1350 & 1365 & 1324 & 1461 & 1216 & 1334 & 1309 \\
\hline \multicolumn{8}{|c|}{$\begin{array}{l}\text { Standard errors in parentheses } \\
* p<0.10, * * p<0.05, * * * p<0.01 \\
\text { Notes: Trend included. "Dom. Patents" denotes the number of domestic patents, "Imports", "R\&D Imports" } \\
\text { and "FDI" denote spillover effects from foreign knowledge transmitted via total, R\&D-intensive imports and } \\
\text { FDI respectively. "FODI" refers to "Foreign ownership of domestic inventions" and the associated spillover } \\
\text { effect. }\end{array}$} \\
\hline
\end{tabular}

Table 10: Mean-group CCE, with trend

\begin{tabular}{|c|c|c|c|c|c|c|c|}
\hline & $\begin{array}{c}\text { (1) } \\
\text { TFP }\end{array}$ & $\begin{array}{c}(2) \\
\text { TFP }\end{array}$ & $\begin{array}{c}(3) \\
\text { TFP }\end{array}$ & $\begin{array}{c}\text { (4) } \\
\text { TFP }\end{array}$ & $\begin{array}{c}(5) \\
\text { TFP }\end{array}$ & $\begin{array}{c}(6) \\
\text { TFP }\end{array}$ & $\begin{array}{c}(7) \\
\text { TFP }\end{array}$ \\
\hline Dom Patents & $\begin{array}{c}0.009 \\
(0.006)\end{array}$ & $\begin{array}{c}0.006 \\
(0.006)\end{array}$ & $\begin{array}{c}0.004 \\
(0.007)\end{array}$ & $\begin{array}{c}0.008 \\
(0.017)\end{array}$ & $\begin{array}{c}0.010 \\
(0.009)\end{array}$ & $\begin{array}{c}0.006 \\
(0.023)\end{array}$ & $\begin{array}{c}-0.003 \\
(0.020)\end{array}$ \\
\hline Imports & $\begin{array}{c}0.058 * * * \\
(0.012)\end{array}$ & & & & $\begin{array}{c}0.054^{* * *} \\
(0.015)\end{array}$ & $\begin{array}{c}0.052^{* * *} \\
(0.012)\end{array}$ & \\
\hline R\&D Imports & & $\begin{array}{c}0.054^{* * *} \\
(0.009)\end{array}$ & & & & & \\
\hline FDI & & & $\begin{array}{l}0.003^{*} \\
(0.002)\end{array}$ & & $\begin{array}{l}-0.000 \\
(0.001)\end{array}$ & & $\begin{array}{l}0.004^{* *} \\
(0.002)\end{array}$ \\
\hline FODI & & & & $\begin{array}{c}0.015 \\
(0.017) \\
\end{array}$ & & $\begin{array}{c}0.020 \\
(0.022)\end{array}$ & $\begin{array}{c}0.025 \\
(0.019)\end{array}$ \\
\hline Observations & 1350 & 1365 & 1324 & 1461 & 1216 & 1334 & 1309 \\
\hline
\end{tabular}

Standard errors in parentheses

${ }^{*} p<0.10,{ }^{* *} p<0.05, * * * p<0.01$

Notes: Trend included. CCE: common correlated effects (estimator). "Dom. Patents" denotes the number of domestic patents, "Imports", "R\&D Imports" and "FDI" denote spillover effects from foreign knowledge transmitted via total, R\&D-intensive imports and FDI respectively. "FODI" refers to "Foreign ownership of domestic inventions" and the associated spillover effect. 
Table 11: Blundell-Bond, with 2 lags

\begin{tabular}{|c|c|c|c|c|c|c|c|}
\hline & $\begin{array}{c}(1) \\
\text { TFP }\end{array}$ & $\begin{array}{c}(2) \\
\text { TFP }\end{array}$ & $\begin{array}{c}(3) \\
\text { TFP }\end{array}$ & $\begin{array}{c}(4) \\
\text { TFP }\end{array}$ & $\begin{array}{c}(5) \\
\text { TFP }\end{array}$ & $\begin{array}{c}(6) \\
\text { TFP }\end{array}$ & $\begin{array}{c}(7) \\
\text { TFP }\end{array}$ \\
\hline Dom Patents & $\begin{array}{c}0.063^{* *} \\
(0.030)\end{array}$ & $\begin{array}{c}0.038 \\
(0.027)\end{array}$ & $\begin{array}{l}-0.035 \\
(0.026)\end{array}$ & $\begin{array}{c}0.096^{* *} \\
(0.039)\end{array}$ & $\begin{array}{l}-0.009 \\
(0.031)\end{array}$ & $\begin{array}{l}0.085^{*} \\
(0.047)\end{array}$ & $\begin{array}{c}0.051 \\
(0.044)\end{array}$ \\
\hline Imports & $\begin{array}{c}0.047 \\
(0.030)\end{array}$ & & & & $\begin{array}{c}0.040 \\
(0.037)\end{array}$ & $\begin{array}{c}0.052^{* *} \\
(0.025)\end{array}$ & \\
\hline R\&D Imports & & $\begin{array}{c}0.026 \\
(0.020)\end{array}$ & & & & & \\
\hline FDI & & & $\begin{array}{c}0.008 \\
(0.005)\end{array}$ & & $\begin{array}{c}0.002 \\
(0.005)\end{array}$ & & $\begin{array}{c}0.009^{*} \\
(0.005)\end{array}$ \\
\hline FODI & & & & $\begin{array}{c}-0.063^{*} \\
(0.037) \\
\end{array}$ & & $\begin{array}{c}-0.056 \\
(0.036) \\
\end{array}$ & $\begin{array}{c}-0.039 \\
(0.034) \\
\end{array}$ \\
\hline Observations & 1264 & 1278 & 1140 & 1384 & 1039 & 1248 & 1129 \\
\hline hansenp & 0.416 & 0.222 & 0.343 & 0.189 & 0.795 & 0.932 & 0.987 \\
\hline $\operatorname{ar} 2 \mathrm{p}$ & 0.586 & 0.723 & 0.842 & 0.892 & 0.493 & 0.580 & 0.751 \\
\hline
\end{tabular}

Standard errors in parentheses

${ }^{*} p<0.10,{ }^{* *} p<0.05,{ }^{* * *} p<0.01$

Notes: "Dom. Patents" denotes the number of domestic patents, "Imports", "R\&D Imports" and "FDI" denote spillover effects from foreign knowledge transmitted via total, R\&D-intensive imports and FDI respectively. "FODI" refers to "Foreign ownership of domestic inventions" and the associated spillover effect. "hansenp" plots the p-value of the Hansen (Null hyp.: over-id restrictions valid) and "ar2p" the p-value of the autocorrelation test of order 2 (Null hyp.: no autocorrelation). 
Table 12: Countries included in the dataset

\begin{tabular}{lll}
\hline \hline Albania & Hong Kong & Portugal \\
Algeria & Hungary & Qatar \\
Argentina & Iceland & Romania \\
Australia & India & Russia \\
Austria & Indonesia & Saudi Arabia \\
Bahrain & Iran & Senegal \\
Bangladesh & Iraq & Singapore \\
Barbados & Ireland & Slovak Republic \\
Belgium & Israel & Slovenia \\
Bolivia & Italy & South Africa \\
Bosnia and Herzegovina & Jamaica & Spain \\
Brazil & Japan & Sri Lanka \\
Burkina Faso & Jordan & St. Lucia \\
Cambodia & Kenya & Sudan \\
Cameroon & Korea, Republic of & Sweden \\
Canada & Kuwait & Switzerland \\
Chile & Luxembourg & Syria \\
China & Macedonia & Taiwan \\
Colombia & Madagascar & Tanzania \\
Costa Rica & Malawi & Thailand \\
Cote d'Ivoire & Malaysia & Trinidad \& Tobago \\
Croatia & Mali & Tunisia \\
Cyprus & Malta & Turkey \\
Czech Republic & Mexico & Uganda \\
Denmark & Morocco & United Arab Emirates \\
Dominican Republic & Mozambique & United Kingdom \\
Ecuador & Netherlands & United States \\
Egypt & New Zealand & Uruguay \\
Estonia & Niger & Uzbekistan \\
Ethiopia & Nigeria & Venezuela \\
Finland & Norway & Vietnam \\
France & Oman & Yemen \\
Germany & Pakistan & Zambia \\
Ghana & Peru & Zimbabwe \\
Greece & Philippines & \\
Guatemala & Poland & \\
\hline \hline & & \\
\hline
\end{tabular}

